\title{
Spontaneous pneumothorax and ozone levels: is there a relation?
}

C'è un rapporto tra pneumotorace spontaneo e livelli di 0zono?

\author{
Yasin Abul ${ }^{1}$, Sait Karakurt², Korkut Bostanci ${ }^{3}$, Mustafa Yuksel ${ }^{3}$, Emel Eryuksel ${ }^{4}$, Serdar Evman ${ }^{3}$, \\ Turgay Celikel² \\ ${ }^{1}$ Ministry of Health Bismil Government Hospital, Pulmonary Medicine Clinics, Diyarbakir, Turkey \\ ${ }^{2}$ Marmara University, Faculty of Medicine, Department of Pulmonary and Critical Care, Istanbul, Turkey \\ ${ }^{3}$ Marmara University, Faculty of Medicine, Department of Thoracic Surgery, Istanbul, Turkey \\ ${ }^{4}$ Ministry of Health Yedikule Chest Diseases and Thoracic Surgery Research and Education Hospital, Critical Care \\ Unit, Istanbul, Turkey
}

\begin{abstract}
Study objectives: Although links between meteorological conditions and spontaneous pneumothorax (SP) have been proposed, the reports are controversial. In this study ozone levels, which are known to have some adverse effects on lung tissues, were investigated as a potential triggering factor of SP. At present there is not sufficient information about the effects of ozone on SP.

Methods: Of a total 79 pneumothorax patients recruited for the study, 21 secondary pneumothorax cases were excluded. In the remaining $58 \mathrm{SP}$ patients, meteorological data at the time of SP occurrence were recorded.

Results: The number of SP patients was higher in spring than in the other seasons $(p<0.05)$. There was an association between the SP frequency and the average ozone level at different seasons $(F 3,52=19.45, P=0.001)$. The average ozone level was higher in spring (363 \pm 25 Dobson) than during the other seasons (autumn $296 \pm 18$ Dobson; summer $321 \pm 26$ Dobson; winter $324 \pm 32$ Dobson) $(p=0.001)$. There was a positive correlation between SP frequency and the average ozone values for each season $(r=0.301, p=0.024)$. There was no significant correlation between the severity of SP and ozone level $(r=0.236, p=0.16)$.

Conclusions: The number of SP patients increases in spring when ozone levels are highest. Ozone is known to affect alveolar cells and cause interstitial edema. Ozone causes damage to the lung interstitium by way of oxidative stress. Rupture of unrecognized underlying blebs/bullae has been proposed as a cause of SP. Increased levels of ozone may be a triggering factor for these ruptures.
\end{abstract}

Keywords: Ozone, seasonality, spontaneous pneumothorax.

\section{RIASSUNTO}

Obiettivi: Sebbene siano state proposte possibili connessioni tra le condizioni meteorologiche e lo pneumotorace spontaneo (SP), i risultati sono ad oggi contoversi. In questo studio i livelli di ozono, del quale sono noti gli effetti dannosi per le strutture polmonari, sono stati oggetto di valutazione come possibili fattori causali nel SP. Al momento attuale le informazioni sugli effetti dell'ozono sul SP non sono sufficienti.

Metodi: Su un totale di 79 pazienti con pneumotorace reclutati per lo studio ne sono stati esclusi 21 perché lo pneumotorace era secondario. Nei rimanenti 58 pazienti con SP sono stati registrati i dati meteorologici alla data dell'evento.

Risultati: Il numero dei pazienti con SP era maggiore in primavera rispetto alle altre stagioni $(p<0,05)$. Si è rilevata un'associazione tra la frequenza di SP e i livelli medi di ozono nelle varie stagioni ( $F 3,52=19,45 ; P=0,001$ ). Il livello medio di ozono era maggiore in primavera (363 \pm 25 Dobson) rispetto alle altre stagioni (autunno $296 \pm 18$ Dobson; estate $321 \pm 26$ Dobson; inverno 324 土 32 Dobson) $(p=0,001)$. Si è rilevata una correlazione positiva tra frequenza di SP e valori medi di ozono in ogni stagione $(r=0,301$, $p=0,024)$, mentre non vi erano correlazioni significative tra la gravità del SP ed i livelli di ozono $(r=0,236, p=0,16)$.

Conclusioni: Il numero di pazienti con SP aumenta in primavera quando i livelli di ozono sono massimi. È risaputo che l'ozono provoca danni sulle cellule dell'alveolo polmonare e causa edema interstiziale, danneggiando l'interstizio polmonare mediante stress ossidativo. La rottura di bolle e bollicine di cui il paziente è portatore inconsapevole è il meccanismo abitualmente attribuito come causa del SP: i maggiori livelli di ozono potrebbero essere un fattore scatenante di queste rotture.

Parole chiave: Ozono, pneumotorace spontaneo, stagionalità.

\footnotetext{
$\equiv$ Yasin Abul

Ministry of Health Bismil Government Hospital, Pulmonary Medicine Clinics, Diyarbakir, Turkey

Ataturk M. Tantavi C. No:52/7 Umraniye-Istanbul, Turkey

email: abulyasin@yahoo.com
}

Data di arrivo del testo: 30/06/2010 - Accettato dopo revisione: 22/07/2010

Multidisciplinary Respiratory Medicine 2011; 6(1): 16-19 


\section{INTRODUCTION}

Primary spontaneous pneumothorax (SP) is a disease that occurs without a precipitating event in patients with no known lung diseases. In fact, most SPs are usually thought to result from rupture of unrecognized blebs or bullae [1-2]. Triggering factors causing rupture of blebs or bullae have not been determined. The proposed factors for the rupture of blebs or bullae are disequilibrium between pressure in the blebs/bullae and pressure in the surroundings [3]. SP has differing geographical incidences. The reason for these differences are unknown [4]. Certain climate changes, including atmospheric pressure, humidity, temperature and seasonal variations have been studied as a potential cause of SP occurrence [5-7]. However, the results of these studies are controversial and have consistently failed to show an association $[3,8]$. Additional studies are necessary to evaluate the possible triggering factors of SP which may be caused by the rupture of blebs or bullae. The possible impact of changes in ozone level on the occurrence of SP has not been studied before. Similarity between electron microscopic findings of ozone effects on lung tissue and electron microscopic findings of SP encourage us to expect an association between ozone concentration and the occurrence and severity of pneumothorax [9-10]. We aimed to evaluate the association between the occurrence of SP and ozone levels. Such an association may help us to understand the mechanism of SP and the potential triggering factors causing rupture of blebs or bullae which may be the actual cause of SP.

\section{METHODS AND MATERIALS}

A total of 79 consecutive pneumothorax patients who were admitted to emergency outpatient clinics of Marmara University Hospital were included in the study. We subsequently excluded 21 secondary pneumothorax patients; the remaining 58 SP patients were investigated. Meteorological data and ozone levels, recorded at the date and time of the SP occurence at that latitude and longitude, were obtained from a website of the Total Ozone Mapping Spectrometer, Ozone Processing TeamNASA/GSFC Code 613.3. Pearson's $\chi^{2}$, analysis of variance, the $t$-test and the Pearson correlation coefficient were used as the statistical measures.

\section{RESULTS}

The female/male ratio was $7 / 51$ while mean age was $39 \pm 30$ years for females and $35 \pm 17$ years for males. Demographic characteristics and risk factors including smoking did not differ significantly in patients presenting in different seasons (Table I). The number of SP patients was higher in spring than in other seasons (spring $\mathrm{n}=25$, summer $\mathrm{n}=12$, autumn $=12$, winter $=9 ; p<0.05)$. Numbers of SP patients were higher in March $(n=6)$, April $(n=11)$, May $(n=8)(p<0.05)$ than in any of the other months. There was an association between the frequency of SP incidence and the average ozone level for the different seasons (F 3,52 = 19.45, $p=0.001)$. As Figure 1 shows, the average ozone level was higher in spring (363 \pm 25 Dobson) than in the other seasons (autumn, $296 \pm 18$ Dobson; summer, $321 \pm 26$ Dobson; winter, $324 \pm 32$ Dobson) $(p=$ 0.001). There was a positive correlation between SP frequency and the average ozone values for the seasons $(r=0.301, p=0.024)$. There was no significant correlation between the severity of SP and ozone levels $(r=0.236, p=0.16)$.

\section{DISCUSSION}

This is the first study examining the effects of ozone levels on spontaneous pneumothorax occurrences. Some previous studies have proposed that seasonality and especially atmospheric pressure may be precipitating factors for SP. Bense and Scott et al. had previously shown the link between SP and changes in atmospheric pressure $[5,11]$. However, more recent studies in different regions have failed to show an association between SP and climate changes [12-14]. Recently, the first large nationwide population based study did not support the premise that seasonality is a precipitating factor for SP [8]. In all these studies, humidity, atmospheric pressure changes and temperatures were under consideration in relation to the spontaneous pneumothorax occurrences. Many studies have demonstrated no association of changes in atmospheric pressure in different regions and SP. Also with regard to SP and variations in ambient temperature, some studies have revealed no relationships. The results from these studies are controversial, but they have consistently failed to show a significant association.

The most important finding of our study was the increased number of patients with SP during periods of high ozone levels. The increased SP frequency may be due to the oxidative stress effect of ozone. Ozone is known to cause damage to the lung interstitium by way of oxidative stress [15]. Ozone has also been known as a protoplasmic poison causing damage to lung tissue during lung exposure to chlorine [16]. Studies of the noxious effects of ozone on lung tissues are limited but it is known that ozone can cause damage in lung tissue. Previously, acute ozone exposure has been shown to decrease lung volume per unit of distending pressure. This effect may be potentially caused by a change of lung tissue elasticity or by changes in surface tension forces of the alveoli [10]. The lungs are constantly exposed to oxidants which are present in the air inhaled. The oxidants in inhaled air include cigarette smoke and ozone, or those released from inflammatory leukocytes. These oxidants, including ozone, cause direct damage to the lung interstitium. These oxidative stressors have been shown to contribute to the pathogenesis of SP in some studies [15]. An increase in interstitial mass and a proliferation of epithelial cells has been reported as a response to pulmonary stress and insult including exposure to 


\begin{tabular}{|c|c|c|c|c|c|}
\hline Characteristics & Spring $(n=25)$ & Summer $(n=12)$ & Autumn $(n=12)$ & Winter $(n=9)$ & $P$ \\
\hline Male/Female & $21 / 4$ & $11 / 1$ & $11 / 1$ & $8 / 1$ & 0.87 \\
\hline Age (years) & $40 \pm 20$ & $31 \pm 15$ & $30 \pm 18$ & $34 \pm 18$ & 0.43 \\
\hline Smoking History +/- & $18 / 7$ & $10 / 2$ & $7 / 5$ & $7 / 2$ & 0.56 \\
\hline \multicolumn{6}{|l|}{ Severity of SP } \\
\hline Moderate & 13 & 3 & 5 & 6 & \\
\hline Severe & 4 & 4 & 3 & 0 & 0.28 \\
\hline Undefined** & 8 & 5 & 4 & 3 & \\
\hline
\end{tabular}

*Data are presented as mean \pm SD or absolute numbers.

**SP patients who did not have chest $\mathrm{X}$-rays because of emergency conditions.

ozone [9]. By way of these effects on lung tissue, increased levels of ozone in the inhaled air may contribute to the pathogenesis and occurrence of SP. The other important finding of our study was the increased SP frequency in the spring. There was also a positive correlation between SP frequency and average ozone values for the seasons. The average ozone value was higher in spring, and in spring there was an increased SP frequency. In the literature there is no consensus regarding the causes of the apparent increase in the rate of SP. There is also no agreement about factors causing the occurrence of SP. Some studies have proposed that changes in atmospheric pressure cause alterations of the volume of air-holding lung cysts, and that this may cause weakening of the walls [3]. However, both weakening of the walls due to atmospheric changes and contributions from other seasonal factors in-

FIGURE 1: NUMBER OF SPONTANEOUS PNEUMOTHORAX PATIENTS AND OZONE LEVEL ACCORDING TO SEASONS

$$
\begin{aligned}
& 25(43.1 \%), \text { Spring } \quad \Delta 12(20.7), \text { Autumn } \\
& 12(20.7 \%), \text { Summer } \quad \times 9(15.5), \text { Winter }
\end{aligned}
$$

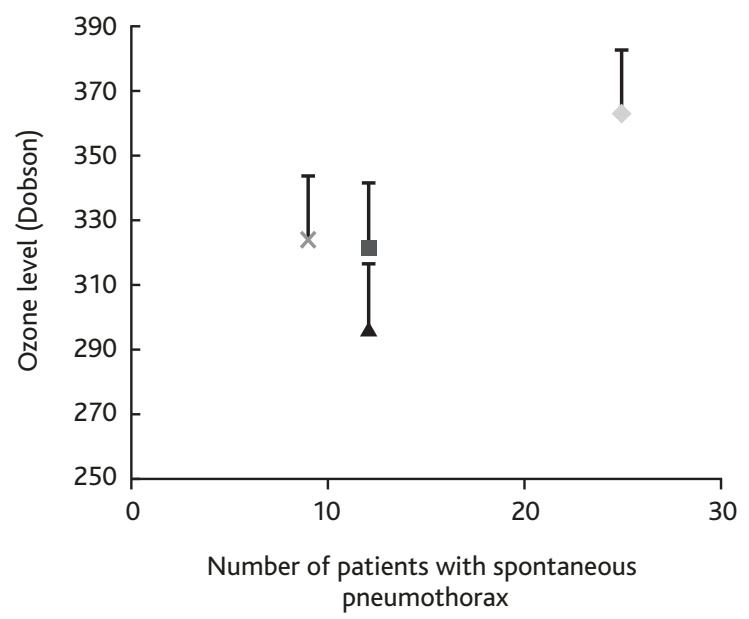

cluding temperature, humidity and storms as an explanation for the occurrence of SP do not provide strong explanations for the SP occurrence from the point of view of pathophysiology.

In our study, we found that SP was more often seen in high ozone levels. Ozone itself is known to have some destructive effects on lung tissue. This has been shown by both biochemical studies and by electron microscopical studies $[10,15,17]$. It is also interesting that similar ultrastructural changes are seen in lungs both in response to acute ozone exposure and in the occurrence of spontaneous pneumothorax. These changes include proliferation of epithelial cells and an increase in the intersitial mass and edema [9-10]. As certain climatic parameters have shown weak and controversial associations with the incidence of SP, there is a need to invesitigate possible other associations. From our findings and from the potential pathophysiological mechanisms of ozone acting on lung tissue, a high level of ozone may be a precipitating factor in the alteration of lung tissue elasticity and may also be a factor in the rupture of blebs/bullae in SP. In our study a high level of ozone in the spring may explain the more frequent occurrence of SP in this season.

\section{Limitations}

The first limitation is the small sample size of the study. A larger sample would have provided more precise information about the effect of ozone level on the occurrence and severity of SP. A second limitation is that this study is an uncontrolled retrospective study that could have a recall bias.

\section{CONCLUSIONS}

We found a higher incidence of SP in the spring months when the ozone levels were highest. There was a positive correlation between SP frequency and average ozone values for the seasons in our study. A high level of ozone may be involved in the pathogenesis of SP. Larger population-based studies in addition to the animal studies for effect of ozone level on SP should be carried out to assess this relationship. 


\section{ACKNOWLEDGEMENT}

The authors would like to thank Prof. RW Guillery from University of Oxford for the English correction of the manuscript.

\section{References}

1. Schramel FM, Postmus PE, Vanderschueren RG. Current aspects of spontaneous pneumothorax. Eur Respir J 1997; 10:1372-1379.

2. Sahn SA, Heffner JE. Spontaneous pneumothorax. N Engl J Med 2000;342:868-874.

3. Smit HJ, Devillé WL, Schramel FM, Schreurs JM, Sutedja TG, Postmus PE. Atmospheric pressure changes and outdoor temperature changes in relation to spontaneous pneumothorax. Chest 1999; 116:676-681.

4. Light R. Pleural Diseases. $4^{\text {th }}$ ed. Philadelphia: Lippincott, Williams and Wilkins, 2001.

5. Bense L. Spontaneous pneumothorax related to falls in atmospheric pressure. Eur J Respir Dis 1984;65:544-546.

6. Ozenne G, Poignie P, Lemercier JP, Nouvet G, Grancher G. Meteorological conditions and spontaneous pneumothorax. Retrospective study of 165 cases in the Rouen area. Rev Pneumol Clin 1984;40:27-33.

7. Alifano M, Forti Parri SN, Bonfanti B, Arab WA, Passini A, Boaron $\mathrm{M}$, Roche N. Atmospheric pressure influences the risk of pneumothorax: beware of the storm! Chest 2007;131:1877-1882.

8. Chen $\mathrm{CH}$, Kou YR, Chen CS, Lin HC. Seasonal variation in the incidence of spontaneous pneumothorax and its association with climate: a nationwide population-based study. Respirology 2010;15:296-302.

9. Tueller EE, Crise NR, Belton JC, McLaughlin RF Jr. Idiopathic spontaneous pneumothorax. Electron micro-
CONFLICT OF INTEREST STATEMENT: None of the authors has any conflict of interest to declare in relation to the subject matter of this manuscript.

scopic study. Chest 1977;71:419-421.

10. Boatman ES, Frank R. Morphologic and ultrastructural changes in the lungs of animals during acute exposure to ozone. Chest 1974;65(Suppl):9S-11S.

11. Scott GC, Berger R, McKean HE. The role of atmospheric pressure variation in the development of spontaneous pneumothoraces. Am Rev Respir Dis 1989;139:659-662.

12. Ayed AK, Bazerbashi S, Ben-Nakhi M, Chandrasekran C, Sukumar M, Al-Rowayeh A, Al-Othman M. Risk factors of spontaneous pneumothorax in Kuwait. Med Princ Pract 2006;15:338-342.

13. Bulajich B, Subotich D, Mandarich D, Kljajich RV, Gajich $\mathrm{M}$. Influence of atmospheric pressure, outdoor temperature, and weather phases on the onset of spontaneous pneumothorax. Ann Epidemiol 2005;15:185-190.

14. Suarez-Varel MM, Martinez-Selva MI, Llopis-Gonzalez A, Martinez-Jimeno JL, Plaza-Valia P. Spontaneous pneumothorax related with climatic characteristics in the Valencia area (Spain). Eur J Epidemiol 2000;16:193-198.

15. Tabakoglu E, Ciftci S, Hatipoglu ON, Altiay G, Caglar T. Levels of superoxide dismutase and malondialdehyde in primary spontaneous pneumothorax. Mediators Inflamm 2004;13:209-210.

16. Banyai AL. Paper. Chest 1974;66:540.

17. Alpert SM, Gardner DE, Hurst DJ, Lewis TR, Coffin DL. Effects of exposure to ozone on defensive mechanisms of the lung. J Appl Physiol 1971;31:247-252. 